\section{Global Journal of Business, Economics and Management}

\author{
Volume 07, Issue 1, (2017) 62-68
}

www.wjbem.eu

\title{
Determination of standard times for process improvement: A case study
}

Mehmet Akansel*, Department of Industrial Engineering, Faculty of Engineering, Uludag University, Gorukle Campus, Bursa 16059, Turkey.

Betul Yagmahan, Department of Industrial Engineering, Faculty of Engineering, Uludag University, Gorukle Campus, Bursa 16059, Turkey.

Erdal Emel, Department of Industrial Engineering, Faculty of Engineering, Uludag University, Gorukle Campus, Bursa 16059, Turkey.

\section{Suggested Citation:}

Akansel, M., Yagmahan, B. \& Emel, E. (2017).Determination of standard times for process improvement: A case study. Global Journal of Business, Economics and Management: Current Issues. 7(1), 62-68.

Received October 25, 2016; revised January 29, 2017; accepted March, 2017;

Selection and peer review under responsibility of Prof. Dr. Andreea Iluzia IACOB, Bucharest Academy of Economic Studies, Romania.

${ }^{\circ}$ 2017SciencePark Research, Organization \& Counseling. All rights reserved.

\begin{abstract}
The companies are required to use proper methods to reduce their costs and increase productivity levels so that they can survive in the fast-changing competitive conditions of the existing business environment. Work study is one of those highly effective productivity improvement methods in labor dependent industries. Determination of standard times, which is one of the important steps of a work study, provides a critical input for process improvement activities within companies. This work is based on a project which included determination of standard times as one of the earliest steps of process improvement activities in a steel-pipe manufacturing company. In systems analysis phase which was performed as the first step, it was observed that long delays occurred on production lines and an evenly distribution of workload among workers was not achievable most of the times. In order to alleviate these problems, all labor-intensive jobs within the system were identified and depicted in process charts. Standard times of the processes were determined by using time study and work sampling techniques. Next, line balancing problems associated with uneven workloads were addressed using these standard times data and some solutions were obtained. All in all, the framework which provided promising results in this pilot study was recommended to be broadened to the entire manufacturing system of the company.
\end{abstract}

Keywords: time study, work sampling, standard time, productivity.

\footnotetext{
* ADDRESS FOR CORRESPONDENCE: Mehmet Akansel, Department of Industrial Engineering, Faculty of Engineering, Uludag University, Gorukle Campus, Bursa 16059, Turkey. E-mail address:akansel@uludag.edu.tr / Tel.: +9-0-224-294-2084; fax: +9-0-224-294-1903.
} 


\section{Introduction}

Due to scarcity of the sources used in the creation of goods and services, companies are ought to seek for improvements in the way that they perform their processes so that they can remain in the business. In order to motivate and support these efforts, some well-performing tools and techniques of process improvement are getting bundled under several fancy names, such as "lean manufacturing", "world-class manufacturing" and so on. Actually, some of these newly coined phrases have some roots in the era of "scientific management" termed by F.W. Taylor. Even though all companies desire the fruitful results of improved processes, they are mostly lack of standard times to be used for efficiently utilizing the current capabilities and providing a base for further improvement. Work study provides an indispensable set of tools to analyze and improve the content of the laborrelated processes. By properly applying work study, companies are able to reduce costs and increase productivity so as to become more successful in the challenging business conditions. The stage of method study, which is the initial step of work study, critically analyzes an existing process while providing helpful insights for improvement. The stage of work measurement, which is the second step of work study, focuses on obtaining the time required to perform a certain method. After properly completing the stages of work study, a company is able to run its processes up to their true potentials.

This research covers an industrial application of work study and workload balancing in a steel-pipe manufacturing company. This company has several production lines, each of which having a producttype layout that is in line with requirements of a major product family. At the beginning of the project, the company did not have properly determined standard times for its products and needed to provide additional but sometimes redundant workers for stations with a possibility of causing stoppages on the flow of the products due to workload balancing problems. This project has introduced a framework of work measurement and workload balancing to the company so that it can benefit from workforce savings as a result of properly allotted manual operations among workers.

\section{System Analysis and Problem Definition}

This work was completed in a steel-pipe manufacturing company. The company manufactures plumbing, drilling, natural gas and petroleum line pipes. In the production line, which was the subject of this study, petroleum line pipes with a length of 6-18 meters and a diameter of 4-12 inches which are compatible with API (American Petroleum Institute) standards, water/construction pipes and profiles are being manufactured. These products have varying production processes with individually aligned operations.

In this paper, the product with an alias " $\mathrm{X3}$ " is considered since it has the largest production ratio in the overall products. The process flow of this product group is depicted in Figure 1 . The steel band which is coming from the accumulation station is bent by the rollers to become a pipe and welded by high-frequency welding system both inside and outside. The pipe which is cut by the sawing machine in the demanded length is sent to the alignment station. The pressure rollers in the alignment station remove the curvature of the pipes. The rims of the pipe are counter-bored according to the customer requirements and the pipe is tested under high-pressured hydraulics. Then, an ultra-sound test is performed on the welding line. If the product type requires, length of the pipe and inside and outside burrs are checked. The pipes may be also taken into a varnishing operation according to the customer requirements. At the end of the production line, the marked pipes are stacked and packedin the required quantities. The observations revealed that the workload was not balanced throughout the considered production line and bottlenecks were prevalent. 


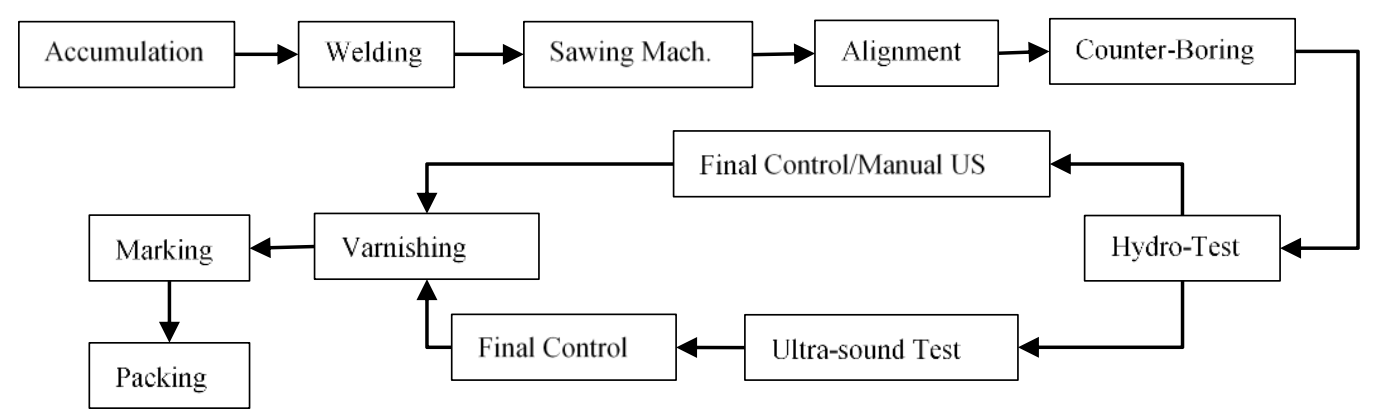

Figure 1. Process Flow Chart

\section{Proposed Approach}

In this work, operations of the stations were analyzed primarily. Later, work study is done to determine the time requirements of major activities. The method of work sampling was applied to obtain the utilization rate of workers, percentages of manual operations, utilization rate of machinery and times of supplementary operations which could not have been determined by work study.

\subsection{Operations Analysis}

This work covers the accumulation and welding stations as a pilot area. There are two employees working at each station making a total of four workers in the pilot area. Primarily, main, secondary and supplementary activities of these stations were identified by observations. These activities are listed in Table 1 and 2.

\subsection{Calculating Standard Times}

Standard times that were determined for the operations of the accumulation and welding stations are shown in Table 3 and Table 4. The ratios indicate the frequency of the operation performed per number of pipes manufactured. When the normal time is calculated, observed time is divided by the frequency. The ratio that indicates the frequency of the operation was considered per roll and normal times were determined for five cycles. Work sampling method was used for supplementary activities that could not have been observed during the period in which work study was done. The software called DesignTool (Niebel et al., 2003) was used in order to generate random observation times and frequencies of all main, secondary and supplementary activities were determined through work sampling observations. The following formula was used to obtain the calculated times of supplementary activities considering the data gathered in the 3-5 hours of observations:

Supplementary Activity Time $=($ SMSAT $) *($ SARWS $/$ MSARWS $)$

Where;

SMSAT: Sum of Main and Secondary Activity Times,

SARWS: Supplementary Activity Ratio in Work Sampling,

MSARWS: Main and Secondary Activity Ratio in Work Sampling. 
Sum of personal, fatigue and other allowances were taken as 10 percent.

\subsection{Balancing Workload}

A Gantt chart was formed to analyze the distribution of workload over time. The Gantt chart graphically shows which sequence of operations provides the assigned workerswith a more balanced workload and a chance of finishing all operations earlier than before. Figure 2 below shows the workload distributions of four employees working at accumulation and welding stations when the pipe $\mathrm{X} 3$ is being manufactured. For each roll, labor ratios were calculated by using the consumption time of the roll. For example, when the pipe $\mathrm{X} 3$ is being manufactured, a roll is consumed in approximately 20 $\min (1,200 \mathrm{sec})(=24$ (pipes) $* 10.5$ (m/pipe) / $12.8(\mathrm{~m} / \mathrm{min}))$. In this case, the first employee is active for 72.6 percent of the time $(=(870.88 / 1200) * 100)$. The second employee is active for 66.6percent of the time $(=(799.50 / 1200) * 100)$.

Table 1. Definitions of major and secondary activities of accumulation station

\begin{tabular}{|c|c|c|c|}
\hline Act. No & Major Activity & Act.No & Secondary Activity \\
\hline ACM.M1 & Steel band is centered on the line & ACM.S1 & Band is carried from stock area to band carriage \\
\hline ACM.M2 & Band circles are cut & ACM.S2 & Band is carried from slitting process \\
\hline ACM.M3 & $\begin{array}{l}\text { Edge of band is aligned and sent to } \\
\text { welding region }\end{array}$ & ACM.S3 & Adding oil to hydraulic center \\
\hline ACM.M4 & Band is adjusted by clamp & ACM.S4 & Cleaning circular pieces in the pit \\
\hline ACM.M5 & $\begin{array}{l}\text { Edge of band is cut and scraps are } \\
\text { discarded }\end{array}$ & ACM.S5 & Cleaning of used up welding rod \\
\hline ACM.M6 & $\begin{array}{l}\text { Band edges are aligned by } \\
\text { pounding with sledge hammer }\end{array}$ & ACM.S6 & Changing empty gas cartridge \\
\hline ACM.M7 & Two edges are welded & ACM.S7 & Cutting the broken part of band \\
\hline ACM.M8 & Edge welding is repaired & ACM.S8 & Taking the unused band back to the stock area \\
\hline ACM.M9 & Main machinery is checked & ACM.S9 & Adjusting the band center \\
\hline ACM.M10 & $\begin{array}{l}\text { Measuring the wall thickness in } \\
\text { both rims of the pipe }\end{array}$ & ACM.S10 & Changing the band pressing wheel \\
\hline ACM.M11 & Data entry to PC and paper form & ACM.S11 & Going to get the copper electrode \\
\hline \multirow[t]{7}{*}{ ACM.M12 } & $\begin{array}{l}\text { Finishing the welding and release } \\
\text { of the pipe }\end{array}$ & ACM.S12 & Changing the copper electrode in the welded area \\
\hline & & ACM.S13 & $\begin{array}{l}\text { Disassembling the parts in the band center and } \\
\text { assembling back }\end{array}$ \\
\hline & & ACM.S14 & Changing the broken crane rope \\
\hline & & ACM.S15 & General repair \\
\hline & & ACM.S16 & Carrying the scrap with crane \\
\hline & & ACM.S17 & Cleaning \\
\hline & & ACM.S18 & Work-related conversation \\
\hline
\end{tabular}


Akansel, M., Yagmahan, B. \& Emel, E. (2017). Determination of standard times for process improvement: A case study. Global Journal of Business, Economics and Management: Current Issues. 7(1), 62-68

Table 2. Definitions of major and secondary activities of welding stations

\begin{tabular}{|c|c|c|c|}
\hline Act. No & Major Activity & Act. No & Secondary Activity \\
\hline WLD.M1 & $\begin{array}{l}\text { Monitoring the process standing by } \\
\text { the line (Main machinery) }\end{array}$ & WLD.S1 & Washing the machine \\
\hline WLD.M2 & $\begin{array}{l}\text { Monitoring the process on the } \\
\text { control panel (General control) }\end{array}$ & WLD.S2 & General repair \\
\hline WLD.M3 & $\begin{array}{l}\text { Monitoring edge welding by walking } \\
\text { alongside the production line }\end{array}$ & WLD.S3 & Silver welding \\
\hline \multirow[t]{2}{*}{ WLD.M4 } & $\begin{array}{l}\text { Adjusting the outside deburring } \\
\text { chisel }\end{array}$ & WLD.S4 & Crushing burrs by crane \\
\hline & Supplementary Activity & WLD.S5 & Going to cut the metallography sample \\
\hline WLD.P1 & Checking the alignment rollers & WLD.S6 & Helping the accumulation crew to broken band \\
\hline WLD.P2 & Adjusting US & WLD.S7 & Work-related conversation \\
\hline WLD.P3 & $\begin{array}{l}\text { Collecting the outside burrs and } \\
\text { discarding }\end{array}$ & WLD.S8 & Collecting the empedor \\
\hline WLD.P4 & $\begin{array}{l}\text { Taking a sample by oxygen (for } \\
\text { inside burr control) }\end{array}$ & & \\
\hline WLD.P5 & Measuring the diameter & & \\
\hline WLD.P6 & Discarding the scrap (by crane) & & \\
\hline WLD.P7 & $\begin{array}{l}\text { Filling out the calibration and } \\
\text { process control form }\end{array}$ & & \\
\hline WLD.P8 & $\begin{array}{l}\text { Filling out the speed-power follow- } \\
\text { up form }\end{array}$ & & \\
\hline WLD.P9 & $\begin{array}{l}\text { Attaching and detaching the inside } \\
\text { burr cutter }\end{array}$ & & \\
\hline WLD.P10 & Checking inside burr & & \\
\hline
\end{tabular}

Table 3. Standard times of operations in accumulation station for product X3

\begin{tabular}{|c|c|c|c|}
\hline \multicolumn{2}{|l|}{ Worker \# 1} & \multicolumn{2}{|l|}{ Worker \#2 } \\
\hline Operation description & time(sec.) & Operation description & time(sec.) \\
\hline Steel band is centered on the line & 53.48 & Main machinery is checked & 237.55 \\
\hline Band circles are cut & 21.58 & $\begin{array}{l}\text { Measuring the wall thickness in both rims } \\
\text { of the pipe }\end{array}$ & 22.73 \\
\hline $\begin{array}{l}\text { Edge of band is aligned and sent to } \\
\text { welding region }\end{array}$ & 94.08 & Data entry to PC and paper form & 74.43 \\
\hline Band is adjusted by clamp & 62.83 & $\begin{array}{l}\text { Finishing the welding and release of the } \\
\text { pipe }\end{array}$ & 259.60 \\
\hline $\begin{array}{l}\text { Edge of band is cut and scraps are } \\
\text { discarded }\end{array}$ & 40.55 & & \\
\hline $\begin{array}{l}\text { Band edges are aligned by pounding with } \\
\text { sledge hammer }\end{array}$ & 62.20 & & \\
\hline Two edges are welded & 188.13 & & \\
\hline Edge welding is repaired & 71.48 & & \\
\hline $\operatorname{Sum}\left(t_{e}\right)$ & 594.30 & $\operatorname{Sum}\left(t_{e}\right)$ & 594.30 \\
\hline Supplementary Activity Time & 217.15 & Supplementary Activity Time & 145.77 \\
\hline Allowance Ratio & $10 \%$ & Allowance Ratio & $10 \%$ \\
\hline Standard Time & 870.88 & Standard Time & 799.50 \\
\hline
\end{tabular}


Akansel, M., Yagmahan, B. \& Emel, E. (2017). Determination of standard times for process improvement: A case study. Global Journal of Business, Economics and Management: Current Issues. 7(1), 62-68

Table 4. Standard times of operations in welding station for product X3

\begin{tabular}{|c|c|c|c|}
\hline \multicolumn{2}{|l|}{ Worker \# 1} & \multicolumn{2}{|l|}{ Worker \# 2} \\
\hline Operation description & time(sec.) & Operation description & time(sec.) \\
\hline $\begin{array}{l}\text { Monitoring the process standing by the } \\
\text { line (Main machinery) }\end{array}$ & & $\begin{array}{l}\text { Monitoring the process standing by the line } \\
\text { (Main machinery) }\end{array}$ & 209.00 \\
\hline $\begin{array}{l}\text { Monitoring the process on the control } \\
\text { panel (General control) }\end{array}$ & 922.50 & $\begin{array}{l}\text { Monitoring the process on the control } \\
\text { panel (General control) }\end{array}$ & 55.00 \\
\hline $\begin{array}{l}\text { Monitoring edge welding by walking } \\
\text { alongside the production line }\end{array}$ & 11.00 & $\begin{array}{l}\text { Monitoring edge welding by walking } \\
\text { alongside the production line }\end{array}$ & 236.67 \\
\hline Adjusting the outside deburring chisel & & Adjusting the outside deburring chisel & 33.00 \\
\hline Checking the alignment rollers & 3.44 & Checking the alignment rollers & 62.00 \\
\hline Adjusting US & & Adjusting US & 55.00 \\
\hline Collecting the outside burrs and discarding & & Collecting the outside burrs and discarding & 88.25 \\
\hline $\begin{array}{l}\text { Taking a sample by oxygen (for inside burr } \\
\text { control) }\end{array}$ & & $\begin{array}{l}\text { Taking a sample by oxygen (for inside burr } \\
\text { control) }\end{array}$ & \\
\hline Measuring the diameter & & Measuring the diameter & \\
\hline Discarding the scrap (by crane) & & Discarding the scrap (by crane) & \\
\hline $\begin{array}{l}\text { Filling out the calibration and process } \\
\text { control form }\end{array}$ & 32.50 & $\begin{array}{l}\text { Filling out the calibration and process } \\
\text { control form }\end{array}$ & \\
\hline Filling out the speed-power follow-up form & & Filling out the speed-power follow-up form & 53.33 \\
\hline $\begin{array}{l}\text { Attaching and detaching the inside burr } \\
\text { cutter }\end{array}$ & & $\begin{array}{l}\text { Attaching and detaching the inside burr } \\
\text { cutter }\end{array}$ & \\
\hline Checking inside burr & & Checking inside burr & 55.00 \\
\hline $\operatorname{Sum}\left(t_{e}\right)$ & $\underline{969.44}$ & $\operatorname{Sum}\left(t_{e}\right)$ & $\underline{847.25}$ \\
\hline Supplementary Activity Time & $10 \%$ & Supplementary Activity Time & $10 \%$ \\
\hline Allowance Ratio & $\underline{180.96}$ & Allowance Ratio & $\underline{55.26}$ \\
\hline Standard Time & 1247.35 & Standard Time & $\overline{987.23}$ \\
\hline
\end{tabular}

Figure 2. Workloads of employees working at accumulation and welding stations when pipe $\mathrm{X} 3$ is being manufactured

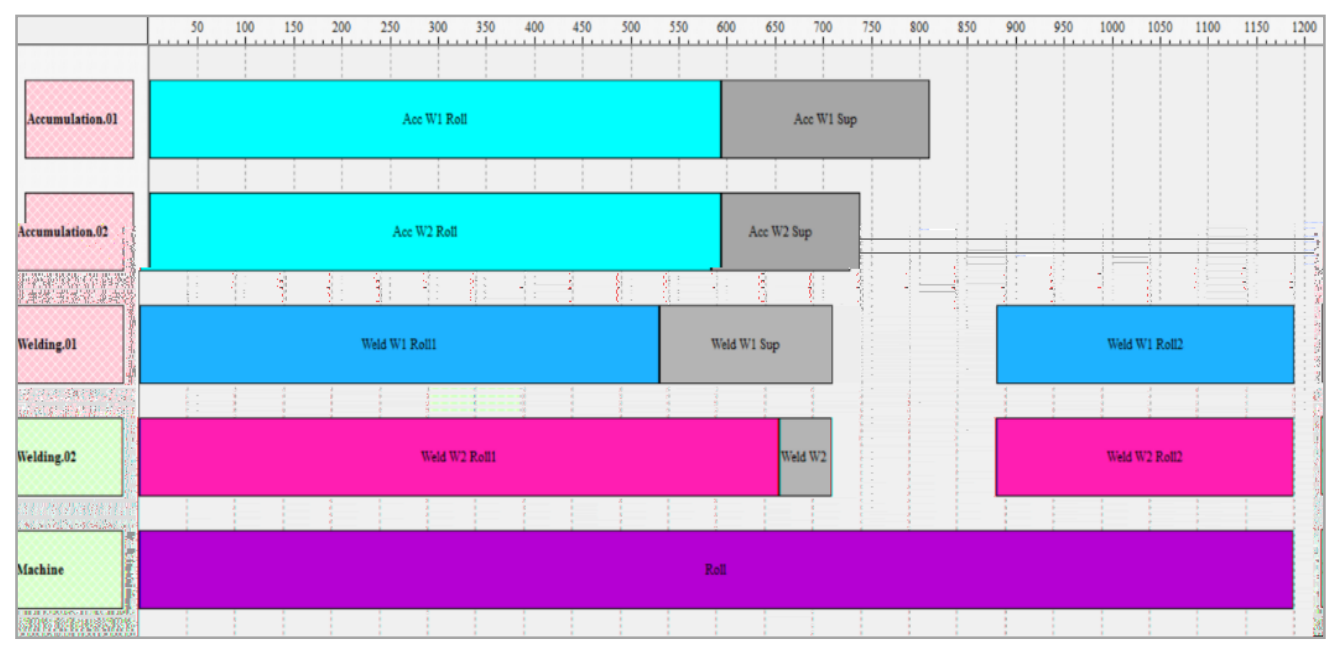




\section{Conclusion}

At the outset of the study, the workloads were not balanced among workers since the company did not have a reliable database of standard times. The workers were struggling and rushing to catch up with main operations on the production line and with supplementary and setup-related operations out of the production line. These unbalanced workload was causing quality problems and unexpected stoppages on the production line. This work has been a pilot study for this company on how to obtain standard times in connected and continuous process lines. We integrated time study and work sampling methods to obtain time data for both direct and indirect operations. The time data was used for balancing the workload of production employees and timetabling to identify when to do the supplementary work without stopping the production line.

\section{Acknowledgements}

We thank our former students, now colleagues, MetinKucuk, FeryalAkkus and Fatih Mehmet Kırıkoglu due their contributionsin thedata collection stages of the project

\section{References}

Al-Saleh, K. S. (2011). Productivity Improvement of a Motor Vehicle Inspection Station Using Motion and Time Study Techniques. Journal of King Saud University - Engineering Sciences, 23, 33-41.

Blay, N., Duffield, C. M., Gallagher, R., \& Roche, M. (2014). Methodological Integrative Review of the Work Sampling Technique Used in Nursing Workload Research. Journal of Advanced Nursing, 70(11), 24342449.

Chase, R. B., Aquilano, N. J., \& Jacobs, F. R. (2001). Operations Management for Competitive Advantage. McGraw-Hill.

Duran, C., Cetindere, A., \& Aksu, Y. E. (2015). Productivity Improvement by Work and Time Study Technique for Earth Energy-glass Manufacturing Company. Procedia Economics and Finance, 26, 109-113.

Ghongadi, T. D., Babu, S. S., \& Kulkarni, M. H. (2015). A Case Study on Operator Workload Balancing for Assembly Stations. International Journal of Engineering Sciences \& Research Technology, 4(11), 369-375.

Gouett, M. C., Haas, C. T., Goodrum, P. M., \& Caldas, C. H. (2011). Activity Analysis for Direct-work Rate Improvement in Construction. Journal of Construction Engineering and Management, 137(12), 11171124.

Gunesoglu, S., \& Meric, B. (2007). The Analysis of Personal and Delay Allowances Using Work Sampling Technique in the Sewing Room of a Clothing Manufacturer. International Journal of Clothing Science and Technology, 19(2), 145-150.

Hendrich, A., Chow, M., Skierczynski, B. A., \& Lu, Z. (2008). A 36-hospital Time and Motion Study: How Do Medical-surgical Nurses Spend Their Time?. The Permanente Journal, 12(3), 25-34.

Hollingsworth, J. C., Chisholm, C. D., Giles, B. K., Cordell, W. H., \& Nelson, D. R. (1998). How Do Physicians and Nurses Spend Their Time in the Emergency Department?. Annals of Emergency Medicine, 31(1), 87-91.

Nabi, F., Mahmud, R., \& Islam, M. M. (2015). Improving Sewing Section Efficiency through Utilization of Worker Capacity by Time Study Technique. International Journal of Textile Science, 4(1), 1-8.

Freivalds, A., \& Niebel, B. (2013). Niebel's Methods, Standards, \& Work Design. New York: McGraw-Hill.

Pelletier, D., \& Duffield, C. (2003). Work Sampling: Valuable Methodology to Define Nursing Practice Patterns. Nursing \& Health Sciences, 5(1), 31-38.

Robinson, M. A. (2010). Work Sampling: Methodological Advances and New Applications. Human Factors and Ergonomics in Manufacturing \& Service Industries, 20(1), 42-60.

Saibani, N., Muhamed, A. A., Maliami, M. F., \& Ahmad, R. (2015). Time and Motion Studies of Manual Harvesting Methods for Oil Palm Fruit Bunches: A Malaysian Case Study. Jurnal Teknologi, 74(3), 77-83.

Tsai, W. H. (1996). A Technical Note on Using Work Sampling to Estimate the Effort on Activities Under Activitybased Costing. International Journal of Production Economics, 43(1), 11-16. 